\title{
Effects of fungal (Lachnocladium spp.) pretreatment on nutrient and antinutrient composition of corn cobs
}

\author{
A. Olagunju*, E. Onyike, A. Muhammad, S. Aliyu and A. S. Abdullahi \\ Department of Biochemistry Ahmadu Bello University, Zaria, Kaduna, Nigeria.
}

Accepted 14 November, 2013

\begin{abstract}
The nutritive value of corn cob following pretreatment by fermentation with fungal species of Lachnocladium spp. was investigated. Corn cob was milled and subjected to incubation with fungal species for a period of one week. Significant increase $(p<0.05)$ in protein, ash and some mineral elements were observed. Calcium, magnesium, zinc and sodium content were observed to be higher in fermented cobs while significant decrease $(p<0.05)$ were observed in the fiber and antinutrient composition. Phytate, saponin, and oxalate levels were particularly lower in the fermented cobs. Biological pretreatment of corn cobs by fermentation with Lachnocladium species was found to significantly improve the nutritive value of corn cob, thus its potential usage in balanced feed for animal product was greatly improved.
\end{abstract}

Key words: Corn cob, nutrients, Lachnocladium spp., fermentation.

\section{INTRODUCTION}

Huge quantities of agro-industrial biomass are produced worldwide annually, although, these materials are potential feed resources for ruminant livestock, their use is limited due to high fiber components (Jarommi et al., 2011). Vast quantities of crop residues are generated as a result of agricultural practices. These residues pose both disposal and environmental pollution problem. These results in the loss of nutritionally valuable materials which when processed could yield various valuable products like biofuels, chemicals and cheap energy sources for fermentation, improved animal feeds and human nutrients (Soliman et al., 2013). There is tremendous potential of agro- industrial by-products and crop residues in upholding the aims of livestock production. However the high amount of lignin content of the residues underscores optimal utilization. Lignin interferes by acting as a physical barrier that prevents the contact of cellulase to cellulose and other nutrients (Umamaheswari et al., 2010). Currently, about eight million metric tonnes of corn are produced annually (Nwanma, 2009) and a production forecast for 2010-2015 envisaged a $23 \%$ growth. The maize plant comprises of the stalks, husks, shanks, silks, leaf blades, leaf sheaths, tassels and cobs. The corn cob carries the grain and together with associating husks, shanks and silks are harvested from the farm. The other parts are left on the farm to rot (Kludze et al., 2010). Corn cob has high percentage of lignin (45\% cellulose, $35 \%$ hemicellulose and $15 \%$ lignin) and has low nutritive value and degradation rate (Sun and Cheng, 2002). This is because rumen micro flora lack enzymes for degradation of lignin and cellulose and hemicellulose are embedded within the lignin structures. Thus, the nutritive values of corn cob not only depend on the availability of nutrient but on such attributes as lignifications and crystallinity of cellulose.

The degree of utilization of crop residues or wastes by livestock is affected by pretreatment (Wong et al., 1991; 
Bolanle et al., 2012). Treatment of crop residues for improving their nutritional value has been undertaken since the beginning of the $20^{\text {th }}$ century (Doyle et al., 1990). Since then, tremendous efforts has been directed towards treatment via physical, physiochemical, chemical and biological means. Physical treatment for example milling and pilleting, soaking, boiling, and steaming leads to increase in surface area and density and an increase in the metabolizable energy (Beadsley, 1993), but have high-energy cost and ineffectiveness in improving feeding value of crop residue. Chemical treatment methods involve steeping by use of chemicals basically acids and alkali like sodium hydroxide and calcium hydroxide. The chemical methods are also more effective compared to the physical methods but their limitations are numerous. Environmental concerns are associated with disposal of spent acids and alkali, and unspecific side reactions which occur to yield non-specific by products. Also, there is requirement of extreme corrosive conditions of high temperature and $\mathrm{pH}$ thus necessitating highly trained personnel and expensive equipment (Grethlein and Converse, 1991; Zhu et al., 2009). Biological treatments with microorganisms such as fungi for example white rot fungi have several advantages when compared with physical and chemical methods. In this case, hydrolysis of polysaccharides occurs via microbial enzymes though fermentation under much milder conditions, do not produce undesirable products and are environmentally friendly (Smith et al., 1997; Rubin, 2008; Palmqvist et al., 2000).

White rot fungi grow well and produce lignocellulosic enzymes under solid state fermentation (SSF) because the medium conditions are closer to their natural habitats. (Salvachúa, 2011; Davinia, 2013). Thus, considering the substantial amount of cobs available for free or sold at very low prices by agro-industries, the upgrading of residues from fermented cobs for use in balanced feed for animal production is of potential advantage (Stamford et al., 2004). This research work has thus been designed to investigate the ability of fungal Lachnocladiun Spp. pretreatment to upgrade the nutrient quality of corn cobs and enhance its potential usage.

\section{MATERIALS AND METHODS}

\section{Collection and preparation of sample}

Air dried corncob residues or agricultural waste were collected in clean bags from Samaru market opposite Ahmadu Bello University main Campus Samaru Zaria. The residues were milled in a mortar and subsequently sieved with a $40 \mathrm{~mm}$ mesh size.

\section{Organism and fermenting conditions}

The test organism Lachnocladium spp. (white rot fungi), was cultivated on potato dextrose agar (PDA) slants until sporulation. The spores were harvested using $0.1 \%$ between 80 and spore number was estimated by direct microscopic counting using a haemocytometer. The white rot fungi was cultivated in mineral salt agroresidue media as described by Ali et al. (1991), in a $250 \mathrm{ml}$ conical flask containing $30 \mathrm{ml}$ in $\mathrm{g} / \mathrm{l}$ of $10.0, \mathrm{KH}_{4} \mathrm{PO}_{4} ; 10.5$, $\left(\mathrm{NH}_{4}\right)_{2} \mathrm{SO}_{4} ; 0.33, \mathrm{MgSO}_{4} .7 \mathrm{H}_{2} \mathrm{O} ; 0.5, \mathrm{CaCl}_{2} ; 0.013, \mathrm{FeSO}_{4} .7 \mathrm{H}_{2} \mathrm{O}$; $0.004, \mathrm{MnSO}_{4} . \mathrm{H}_{2} \mathrm{O} ; 0.5 \%$ yeast extract and $10 \mathrm{~g}$ of corn cobs. The agroresidue media was inoculated with spore suspension of $7.5 \pm$ $10^{5}$ spores $/ \mathrm{ml}$ and incubated at $28 \pm 3^{\circ} \mathrm{C}$. Another set of fermenting conditions was set up as above but without inoculation with the fungi to serve as the unfermented control, while the dried milled residues served as pure control for both media.

\section{Chemical analysis}

The proximate composition of the fermented, unfermented and control samples was carried out. Samples were analyzed for moisture, dry matter, crude protein, lipid, total carbohydrate, fiber, organic matter and mineral matter (ash) using AOAC (1990) methods. Antinutrients components determined include tannin, using Trease and Evans (1978), Saponin (Hudson and El-Difrawi, 1979), Phytate and oxalate (AOAC, 1990) and cyanide (Ikediobi et al., 1980). Sodium and potassium analysis were carried out using flame photometer. Atomic absorption spectroscopy (AAS) was used to determine $\mathrm{Ca}, \mathrm{Fe}, \mathrm{Mn}, \mathrm{Zn}$, and $\mathrm{Mg}$.

\section{Statistical analysis}

Data was subjected to one-way analysis of variance (ANOVA) and least of significant difference (LSD) at 0.05 probability level. All statistical analyses of data were performed using SPSS 17.0 software and the data were reported as mean values \pm standard deviation (SD).

\section{RESULTS}

The effects of fungal fermentation on proximate composition of corn cobs are shown in Table 1. Proximate analysis of all the three group of samples showed significant difference $(p<0.05)$ in the amount of crude protein, ash content and crude fiber in the fermented cobs compared to the unfermented and control corn cobs. Significant difference at $p<0.05$ was not observed in the fat, moisture, total carbohydrate, dry matter and organic matter in all the three group of samples. Table 2 shows the results of mineral analysis on the three groups of samples. Significant difference $(p<0.05)$ was observed in sodium, potassium, and Zinc between the fermented and control samples.

The mineral values for sodium, potassium and zinc in the unfermented samples did not show significant difference when compared to the control and fermented samples except sodium which did not vary significantly with either the fermented or the control samples. Other minerals; calcium, iron, manganese, and magnesium determined in the three samples did not show significant variability. The results of antinutrients analysis on the fermented, unfermented and control samples are shown in Table 3. Significant difference was observed in levels of phytate, saponin, and oxalate as the levels decreased in fermented samples as compared to the unfermented and control samples. Other antinutrients; cyanide and 
Table 1. Effects of Lachnocladium spp. fermentation on proximate composition of corn cobs.

\begin{tabular}{lccc}
\hline Parameter & Fermented cobs & Unfermented cobs & Control \\
\hline Crude protein & $4.79 \pm 0.017^{\mathrm{a}}$ & $4.10 \pm 0.0057^{\mathrm{a}}$ & $3.42 \pm 00.010^{\mathrm{b}}$ \\
Fat & $9.69 \pm 0.005^{\mathrm{a}}$ & $9.96 \pm 0.0059^{\mathrm{a}}$ & $9.55 \pm 0.005^{\mathrm{a}}$ \\
Moisture & $3.98 \pm 0.010^{\mathrm{a}}$ & $5.42 \pm 0.021^{\mathrm{a}}$ & $5.43 \pm 0.017^{\mathrm{a}}$ \\
Ash & $5.69 \pm 0.010^{\mathrm{a}}$ & $4.46 \pm 0.340^{\mathrm{b}}$ & $4.41 \pm 0.004^{\mathrm{b}}$ \\
Carbohydrate & $74.51 \pm 0.006^{\mathrm{a}}$ & $74.51 \pm 0.0055^{\mathrm{a}}$ & $74.51 \pm 0.0061^{\mathrm{a}}$ \\
Fibre & $6.83 \pm 0.023^{\mathrm{a}}$ & $7.72 \pm 0.011^{\mathrm{b}}$ & $7.3- \pm 0.001^{\mathrm{b}}$ \\
Dry matter & $94.55 \pm 0.0058^{\mathrm{a}}$ & $94.56 \pm 0.0056^{\mathrm{a}}$ & $94.52 \pm 0.035^{\mathrm{a}}$ \\
Organic matter & $95.59 \pm 0.0058^{\mathrm{a}}$ & $94.31 \pm 0.011^{\mathrm{a}}$ & $95.34 \pm 0.011^{\mathrm{a}}$ \\
\hline
\end{tabular}

Values are means of triplicate determination \pm standard deviations $(n=3)$. Values not having the same superscript on the row are significantly different $(p<0.05)$.

Table 2. Effect of Lachnocladium spp. fermentation on mineral composition of corn cobs.

\begin{tabular}{lccc}
\hline Parameter & Fermented cobs & Unfermented cobs & Control \\
\hline Calcium & $0.024 \pm 0.0057^{\mathrm{a}}$ & $0.021 \pm 0.0001^{\mathrm{b}}$ & $0.025 \pm 0.010^{\mathrm{a}}$ \\
Sodium & $0.056 \pm 0.0057^{\mathrm{a}}$ & $0.049 \pm 0.005^{\mathrm{ab}}$ & $0.041 \pm 0.005^{\mathrm{b}}$ \\
Potassium & $0.311 \pm 0.50^{\mathrm{a}}$ & $0.241 \pm 0.0057^{\mathrm{b}}$ & $0.241 \pm 0.047^{\mathrm{b}}$ \\
Magnesium & $0.044 \pm 1.00^{\mathrm{ab}}$ & $0.047 \pm 0.010^{\mathrm{a}}$ & $0.031 \pm 0.013^{\mathrm{b}}$ \\
Iron & $0.0025 \pm 0.001^{\mathrm{a}}$ & $0.0024 \pm 0.010^{\mathrm{a}}$ & $0.0024 \pm 0.057^{\mathrm{a}}$ \\
Manganese & $0.0033 \pm 0.0011^{\mathrm{a}}$ & $0.033 \pm 0.011^{\mathrm{a}}$ & $0.0031 \pm 0.019^{\mathrm{a}}$ \\
Zinc & $0.0063 \pm 0.0058^{\mathrm{a}}$ & $0.0018 \pm 0.015^{\mathrm{b}}$ & $0.0018 \pm 0.120^{\mathrm{b}}$ \\
\hline
\end{tabular}

Values are means of triplicate determination \pm standard deviations $(n=3)$. Values not having the same superscript on the row are significantly different $(p<0.05)$.

Table 3. Effect of Lachnocladium spp. fermentation on antinutrients composition in corn cobs.

\begin{tabular}{lccc}
\hline Parameter & Fermented cobs & Unfermented cobs & Control \\
\hline Phytate & $0.803 \pm 0.0057^{\mathrm{a}}$ & $1.32 \pm 0.0061^{\mathrm{b}}$ & $1.32 \pm 0.010^{\mathrm{b}}$ \\
Cyanide & $0.75 \pm 0.005^{\mathrm{a}}$ & $0.75 \pm 0.01^{\mathrm{a}}$ & $0.75 \pm 0.005^{\mathrm{a}}$ \\
Saponin & $2.21 \pm 0.0043^{\mathrm{a}}$ & $3.84 \pm 0.030^{\mathrm{b}}$ & $3.86 \pm 0.032^{\mathrm{b}}$ \\
Tannin & $0.022 \pm 0.002^{\mathrm{a}}$ & $0.024 \pm 0.0033^{\mathrm{a}}$ & $0.024 \pm 0.0083^{\mathrm{a}}$ \\
Oxalate & $0.024 \pm 0.001^{\mathrm{a}}$ & $0.087 \pm 0.005^{\mathrm{b}}$ & $0.088 \pm 0.0055^{\mathrm{b}}$ \\
\hline
\end{tabular}

Values are means of triplicate determination \pm standard deviations $(n=3)$. Values not having the same superscript on the row are significantly different $(p<0.05)$.

tannin were not found to be significantly different in the three samples analyzed.

\section{DISCUSSION}

The proximate analysis of the fermented cobs showed a significant increase in crude protein. The increase in the protein content of the corn cobs fermented with Lachnocladium spp. could be attributed to the possible secretion of laccase and manganese peroxidase and some extracellular enzymes (proteins) such as amylases, and cellulases (Oboh and Akinwumi, 2003) into the fermenting media by the fermenting organism (Sidharth et al., 2013) as well as increase in the growth and proliferation of the fungi in the form of single cell proteins (Omer et al., 2012). Most agricultural wastes are known to support the growth of microorganism as single cell protein and thus enhance feed quality (Sharma and Arora, 2013). For example, fermented cassava has been 
reported for similar potentials by Obuekwe (1993) using Rhizopus as fermenting organism. Fermentation was also seen to generally improve the protein value of the same seed flour (Aderonke and Beatrice, 2013). The reduction of fiber content in fermented corn cobs is of significant importance, as fiber is often used as a negative index of nutritive value in the prediction of total digestible nutrients (TDN) and net energy. It is assume that higher fiber means lower digestibility.

The physical characteristics of fiber (particularly particle size) are also important in regulating rate of passage, rumination, insalivations and the $\mathrm{pH}$ of the rumen (Mahesh and Madhu, 2013). The total fiber or cell wall fraction of plants comprises cellulose, hemicellulose, lignin, cutin, silca and a variety of minor substances. The proportions of these components vary among parts of the same plant and also change as plants mature. The proximate analysis of the fermented, unfermented and control samples did not show any significant difference at $p<0.05$ in the percenttage dry matter, organic matter, moisture, moisture content and crude fat. The dry matter and organic matter are common denominators for comparing nutrient contents of feeds; other determinations in proximate analysis are expressed on dry matter basis. The results obtained have shown that fermentation does not have effect on these compositions.

Another factor limiting the wider feed use of many crop residues is the ubiquitous occurrence of a diverse range of natural compounds which act to reduce nutrient utilization and low food intake which are referred to as antinutritional factors (Osagie, 1998; Sarwar, 2012). Fermentation brings about numerous biochemical and nutritional changes in the raw materials, including the breakdown of certain constituents, the reduction of antinutritional factors and the synthesis of $B$ vitamins (Egounlety and Aworh, 2000). Analysis of fermented corn cobs showed a significant reduction $(p<0.05)$ in the saponin, oxalate, and phytate, while cyanide and tannin did not show significant changes. Saponins are steroid or triterpinoid glycosides which are characterized by their bitter or stringent foaming properties and their hydrolytic effects on red blood cells. But the effectiveness of saponins and other antinutrients depend on the amount present in the feed and effect of pretreatment process on these feeds.

Thus, a significant reduction in the level of the saponin following fermentation is quite advantageous. (Adeniran, 2013). Phytates are hexaphoshate derivative of inositol and storage form of phosphorus in plants. Phytate are insoluble and form salt with metals such as calcium, iron, zinc and magnesium, rendering these metals unavailable for absorption (Osagie, 1998). A reduction in phytate observed in fermented corn cobs may be due to secretion of phytates bond or due to change in the $\mathrm{pH}$ of the medium which affects the attachment of water and thus configuration of phytic acid by altering the strong water molecules attached (Onigbinde, 2005; Adeniran, 2013). The ability of fermentation process to reduce phytate levels have been reported by Mulimani et al. (2003) and Marfo et al. (1990). Oxalate is a dicarboxilic acid anion present as insoluble salts of potassium, sodium and ammonium or as calcium oxalate. It can be toxic when consumed in large quantities. Thus, a reduction in its level through fermentation is quite beneficial to the feeding value of corn cobs. The ash content which is defined as the total mineral was seen to have increased in value. Specific analysis of the mineral elements showed changes in calcium, potassium and zinc. This could be attributed to the effect of fermentation on reducing the levels of antinutrients; phytate and oxalate which increase the bioavailability of mineral elements. (Onyango, 2013)

\section{Conclusion}

Fermentation with white rot fungi could serve as a good means of pre-treating corn cobs to improve its nutritional value, as it has been demonstrated to improve the protein content, fiber level, ash and some mineral elements like calcium, sodium, potassium and zinc. It has also been seen to reduce the level of some antinutrients like saponin, phytate and oxalate. With the combined effects of fungal fermentation on the nutritive value of corn cobs, its usage as an animal feed has been greatly improved. With this alternative use, environmental pollution concerns by maize cobs available for free or sold at very low prices by agro industries and the upgrading of residues from fermented cobs for use in balanced feed for animal production is of potential advantage.

\section{REFERENCES}

Adeniran, HA, Farinde, EO, Obatolu, VA (2013). Effect of heat treatment and fermentation on anti-nutrients content of lima bean (Phaseolus lunatus) during production of Daddawa analogue. Ann. Rev. Res Biol. 3(3):256-266.

Aderonke IO, Beatrice OT, Ifesa (2013). Changes in nutrient and antinutritional contents of sesame seeds during fermentation. J Microbiol. Biotechnol. Food Sci. 2(6)2407-2410.

Ali SS, Saker ART, Akin R (1991). Factors affecting cellulase production by Aspergillus terrus using water hyacinth. World $\mathrm{J}$. Microbiol. Biotechnol. 62-66.

Association of analytical chemist (AOAC 1990) methods of analysis. $15^{\text {th }}$ edition Washington D C.

Beadsley DW (1993). Symposium on forage utilization: Nutritive value of forage as affected by physical form. Part II Beef cattle and sheep studies. J. Anim. Sci. 23:239-245.

Bolanle Kudirat Saliu, Alhassan Sani (2012). Boethanol potentials of corn cob hydrolysed using cellulases of Aspergillus niger and Penicillium decumbens. EXCLI J. 11:468-479.

Davinia S, Angel TM, Ming T, María F L, Francisco G, Vivian R, María J M, and Alicia Pr; (2013) Differential proteomic analysis of the secretome of Irpex lacteus and other white-rot fungi during wheat straw pretreatment. Biotechnol. Biofuels 6:115.

Doyle PT, Pearce GR, Denvendra C (1986). Rice straw as a feed for ruminants. International development programme of Australian Universities and colleges, Canberra Australia. p. 177.

Egounlety, M, Aworh OC. (2000). Biochemical changes in soyabean (Glycine max Merr.), cowpea (Vigna unguiculanta L. Walp), and 
groundbean (Macrotyloma geocarpa Harms) during fermentation with Rhizopus oligosporus. (Paper presented at the International Seminar on Traditional African Fermented Foods. Accra, Ghana). 46, 25.

Grethlien HE and Converse AO (1991). Common aspects of acid prehydrolysis and steam explosion for pretreting wood. Biores. Technol. 38:156-168.

Hudson BJ, El-Difwari KB (1979). The sapogens of the seeds of four Lupin species. J. Plant Foods Human Nutr. 3:181-186.

Ikediobi CO, Onia GO, Eluwa CE (1980). A rapid and intensive enzymatic assay for total cyanide in cassava products. Agric. Biol. Chem. 44(12):2803-2809.

Jaromi MF, Liang M, Rosiarizan YM, Goh P, Shokryazdan YWH (2011). Efficiency of rice straw lignocellulosises degradability by Aspergillus terrus ATCC 74135 in solid state fermentation. Afr. J. Biotech. 10(21):4428-4435.

Kludze H, Deen B, Weersink A, van Acker R, Janovicek K, De Laporte A. (2011). Assessment of the availability of agricultural biomass for heat and energy production in Ontario. 01.27.

Mahesh MS, Madhu M (2013). Biological treatment of crop residues for ruminant feeding. Afric. J. Biotechnol. 12(27):4221-4231.

Marfo EK, Sampson BK, Idowu JS, Oke OL (1990). Effect of local food processing on phytate levels in cassava, cocoyam, yam, sorghum, rice, cowpea and soybeans. J. Agric. Food Chem. 1580-1583.

Mulimani VH, Kadi MS, Thippes Wamy S. (2003). Effect of processing and phytic acid content in different red gram (Cajanus cajan L.) varieties. J. Food Sci. Technol. 40:371-373.

Nwanma V. (2009) Nigerian corn study shows production could more than double: A report presented to government by IITA. Bloomberg.

Oboh G, Akindahunsi AA (2003). Biochemical changes in cassava products (flour and gari) subjected to saccharomyces solid media fermentation. Food Chem. 82(4):599-602.

Obuekwe CO, Okunbgowa JO (1986). Assesment of biomass production of potential of some fungal isolates. Nig. J. Microbiol. 6:120-130.

Omer HAA, Ali FAF, Gad SM (2012). Replacement of clover hay by biologically treated corn stalk in growing sheep rations. J. Agric. Sci. 4:257-268.

Onigbinde AO (2005). Food and human nutrition (Biochemical integration) Revised Ed Alva Corperate org. Benin City 287-334.

Onyango CA, Ochanda SO, Mwasaru MA, Ochieng JK, Mathooko FM, Kinyuru, JN (2013) Effects of malting and fermentation on antinutrient reduction and protein digestibility of red sorghum, white sorghum and pearl millet. J. Food Res. 2(1):41-49.

Osage AU, Offiong UE (1998). Nutritional quality of plat foods, Post Harvest Research Unit. Dept. of Biochemistry University of Benin, Benin City Nigeria. pp. 221-244.

Palmqvist E, Hahn-Hägerdal B (2000): Fermentation of Lignocellulosic hydrolysates. I: inhibition and detoxification. Biores. Technol. 74:1724.

Rubin EM (2008). Genomics of cellulosic biofuels. Nature 454:841-845.

Salvachúa D, Prieto A, López-Abelairas M, Lu-Chau T, Martínez AT, Martínez MJ (2011). Fungal pretreatment: an alternative in secondgeneration ethanol from wheat straw. Biores. Technol. 6:7500-7506.

Sharma RK, Arora DS (2013). Fungal degradation of lignocellulosic residues: An aspect of improved nutritive quality. Crit. Rev. Microbiol. 16:223.
Shereen A. Soliman, Yahia A. El-Zawahry and Abdou A. El-Mougith (2013). Fungal biodegradation of agro-industrial waste licensee InTech. Open access article distributed under the terms of the Creative Commons. pp. 1-28.

Sidharth V, Devendra PM, Mohmed S, Ayushi A and Sangeeta N (2013); Development of microbial consortium for production of blend of enzymes for hydrolysis of agricultural wastes into sugars. J. Sci. Ind. Res. 72:585-590.

Smith JE, Anderson JG, Senior EK (1987). Bioprocessing of lignocelluloses Phill Trans R. Soc. Lond Ser. A 321:507-521

Stanford RB, Guerra NY, Medeiros CP, Defreitas MSR and Cavalcante, M I (2004) Protein enrichment of pineapple waste for animal feeds. In Bioconversion of vegetable, animal and industrial wastes by means of fungi mycelia in an artificial rumen. Laboratory of food sciences Department of nutrition Health Science centre, federal University of Pernambuco Recife, Brazil. pp. 1-5

Sun y and Cheng j (2002) Hydrolysis of lignocellulosic material from ethanol production. A review. Bioresour. Technol. 83:1-11

Trease GE, Evans WC (1978). A textbook of pharmacology $11^{\text {th }}$ Ed MaCraw Hill publishers United Kingdom.

Van Soest PJ (1982) Nutritional ecology of the ruminant Cornell University Press, Ithacaa NY USA.

Wong KKY, Dellerrell KF Keith LM Clerk TA, Donnalson LA (1991). The relationship between fiber porosity and cellulose digestibility in steam exploded pinups. Biotech. Bioeng. 31:447-456.

Zhu JY, Pan XJ, Wang GS, Gleisner R. (2009). Sulfite pretreatment (SPORL) for robust enzymatic saccharification of spruce and red pine. Bioresour. Technol. 100:2411-2418. 